\title{
The Effect of Teacher Training on the Learning Styles of Prospective Teachers of Social Studies
}

\author{
Nevin Özdemir ${ }^{1, *}$, Alper Kesten ${ }^{1}$, Pınar Işkın² \\ ${ }^{1}$ Faculty of Education, Ondokuz May1s University, Turkey \\ ${ }^{2}$ Institute of Educational Sciences, Ondokuz Mayıs University, Turkey
}

Copyright $\bigcirc 2017$ by authors, all rights reserved. Authors agree that this article remains permanently open access under the terms of the Creative Commons Attribution License 4.0 International License

\begin{abstract}
The purpose of this study is to examine the effects of four-year-long undergraduate education on the learning styles of prospective teachers of social studies. This study was conducted in accordance with longitudinal method, which is one of the research designs used in developmental psychology researches. The study was conducted with the participation of 70 prospective teachers of social studies who studied at Ondokuz Mayis University Faculty of Education between 2009 and 2013 and who volunteered to participate in the study. The learning styles of prospective teachers were found by using Kolb's learning styles inventory in the first and last years of their undergraduate education. When the data from this assessment tool were analyzed, it was found that undergraduate education did not cause a significant difference in the perception (concrete experience-abstract conceptualization) and processing (reflective observation-active experimentation) ways in the learning styles of prospective teachers and similar results were found when the variable of gender was taken as the basis.
\end{abstract}

Keywords Kolb Learning Styles, Social Studies Field Education, Prospective Teachers, Longitudinal Method

\section{Introduction}

The learning is the main determinant of human development and individuals have different preferences in perceiving new information and processing this newly perceived information. These different preferences have caused the emergence of the concept of individual learning styles. Recently, studies conducted in the field of learning styles, which have received an increasing amount of interest in every stage of education, have shown that learning styles are influenced by personality type, educational specialization, career choice, and current job role and tasks [1].

According to David Kolb who is one of the most effective authors in the field of learning styles [1-2], early educational experiences shape people's individual learning styles by instilling positive attitudes toward specific sets of learning skills and by teaching students how to learn [3, p:6]. In addition, one becomes a member of a reference group of peers who share a professional mentality and a common set of values and beliefs about how one should behave professionally. This professional orientation shapes learning style through habits acquired in professional training and through the more immediate normative pressures involved in being a competent professional [3, p:7]. In higher education, students generally choose to study in academic disciplines that reflect their own skills and interests. For students, education in an academic field is a continuing process of selection and socialization to the pivotal norms of the field governing criteria for truth and how it is to be achieved, communicated, and used. The resulting educational system emphasizes specialized learning and development through the accentuation of the student's skills and interests. The student's developmental process is a product of the interaction between his or her choices and socialization experiences in academic disciplines [1,3]. Over time these selection and socialization pressures combine to produce an increasingly impermeable and homogeneous disciplinary culture and correspondingly specialized student orientations to learning [4]. During their undergraduate studies, students are encouraged to think like a mathematician, to feel like a poet and to make decisions like a manager. Kolb argues that different disciplines process, experience and produce knowledge in distinctive ways and so can be seen as operating with distinctive learning style. Learners will tend to gravitate towards a discipline where their learning style is in accord with the type of knowledge production prevalent within it. Educational experience shapes learning styles [4-5]. Furthermore, Kolb argues people choose fields that are this template is formatted according to advice of some experts. Equally, if learning style in adolescents is more fluid than within adults, then it is likely to be influenced by the mode of knowledge production favored in the discipline being studied [6]. 
There is considerable evidence that learning styles vary by discipline [7]. Kolb collected extensive data on learning styles of undergraduates and academic staff in the US and used the results to classify the disciplines [8]. The results of previous studies which have used Kolb's Learning Styles Inventory as an assessment instrument show that there are differences in the dominant learning styles of individuals based on their educational field and occupation [9]. According to the results of these studies, social professions such as education and social work are typified by the accommodating learning style, a way of knowing that is based on contextualism. The science-based professions such as medicine and engineering are characterized by the converging learning style, which is based on formism. The humanities and social sciences are typified by the diverging learning style and are based on the world hypothesis of organicism. Mathematics and the natural sciences are characterized by the assimilating learning style and the world hypothesis of mechanism [3,5,7,9]. At the same time, learning styles are subject area sensitive, and most students perceive different disciplines require different learning strategies. Therefore students are able to adapt or style-flex to meet the requirements of the learning task [10].

When previous studies in the field of learning styles are examined, it can be seen that a great number of studies have been conducted on the learning styles of students studying in departments such as teaching, medicine, engineering, architecture and nursing, which try to give students skills for a specific occupation [11-22]. While different scales have been used in these studies to assess the learning styles of university students, it is remarkable that Kolb Learning Styles Inventory (LSI) has been used extensively in assessing the learning styles of university students.

David Kolb's The Experimental Learning Theory [1-2] claim that effective learning involves four key elements: concrete experience (CE), reflective observation (RO), abstract conceptualization (AC) and active experimentation (AE). Learners ideally move through each stage in turn, and transform their experience into knowledge (Figure 1). According to Kolb, learning requires abilities that are polar opposites. People tend to perceive new information in either a concrete or abstract dimension (CE-AC). And this new information is processed or transformed either through activity or reflection (AE-RO). The horizontal axis is the processing continuum demonstrating a preference for performing tasks on one end (AE) and a preference for watching at the other end (RO). The vertical axis is the perception continuum indicating a preferred learning style based upon feeling at one end (CE) and a preferred learning process based on thinking at the other end (AC). The four quadrants are formed by the intersection of the two axes representing four learning styles derived from a combination of two preferred learning abilities. The combination of these two axes gives the four learning styles (diverging, assimilating, converging, accommodating) each of which has different characteristics $[1,3]$.

An individual with diverging style has $\mathrm{CE}$ and $\mathrm{RO}$ as dominant learning abilities. They are interested in people, they tend to be imaginative and emotional, they have broad cultural interests, and they tend to specialize in the arts.

An individual with an assimilating style has $\mathrm{AC}$ and $\mathrm{RO}$ as dominant learning abilities. The assimilating style is important for effectiveness in information and science career.

An individual with a converging style has $\mathrm{AC}$ and $\mathrm{AE}$ as dominant learning abilities. These learning skills are important for effectiveness in specialist and technology career.

An individual with an accommodating style has CE and $\mathrm{AE}$ as dominant learning abilities. This learning style is important for effectiveness in action-oriented careers such as marketing or sale [4]. 


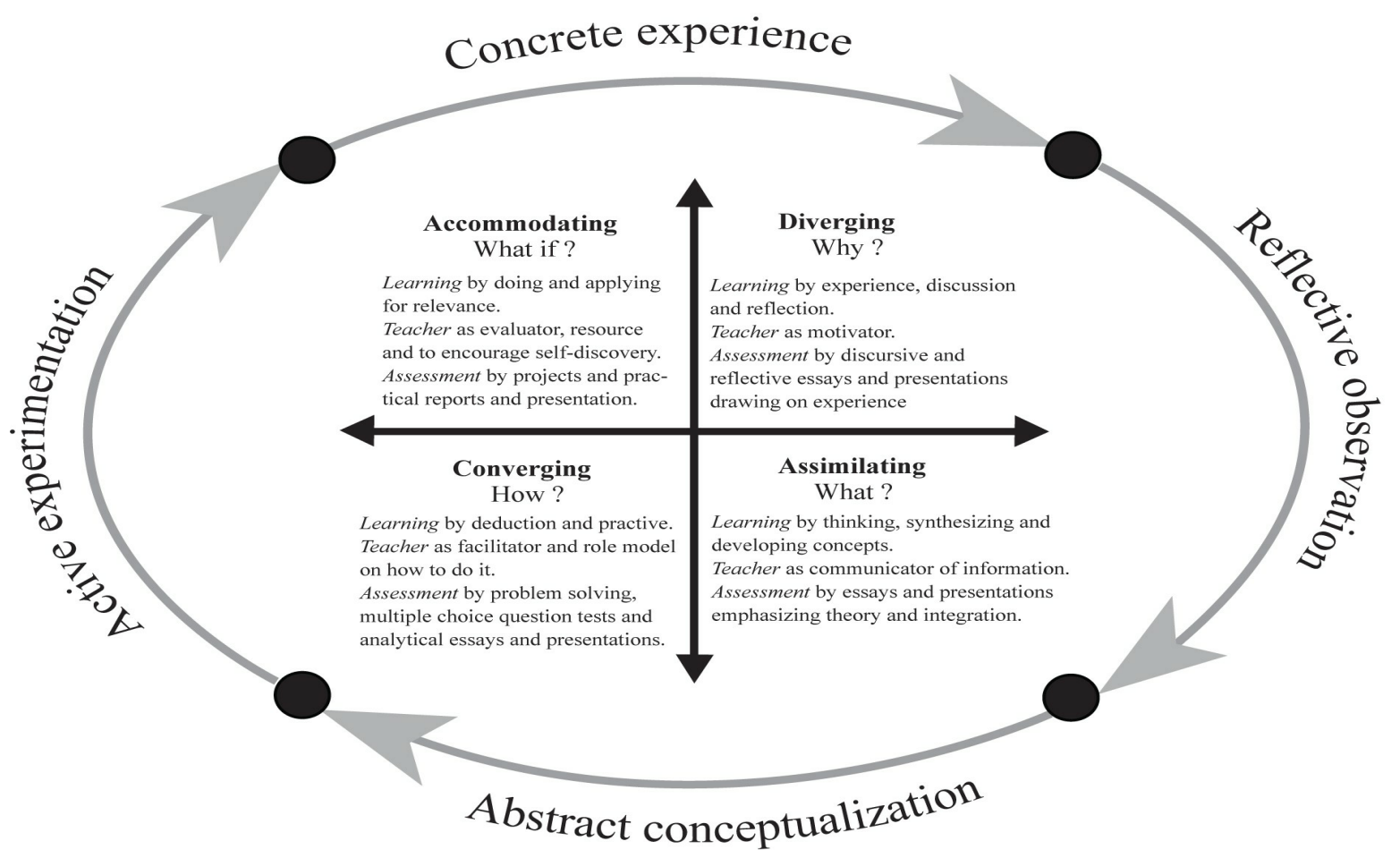

Figure 1. Teaching, learning and assessment activities matches to learning styles of Kolb [53]

In previous studies on learning styles used KLSI as an assessment instrument, it has been identified that dominant learning style of the majority of nursing students are diverging or accommodating [11-16]. Another study reported that the diverging learning style was dominant among Saudi dental students [17]. It is understood from the findings of studies on the learning styles of medicine students that they are predominantly in the diverging or assimilating groups [18-21]. On the other hand, in another study it was stated that the dominant learning styles of the second year undergraduate medical students were assimilating while the dominant learning styles of the residents were converging or accommodating [22]. In a study on the learning styles of architecture students, it was reported that the dominant learning styles of the architecture students were converging or assimilating [23].

According to Kolb, the dominant learning style of those working in the field of education is accommodating [5]. However, previous studies on learning styles of teacher candidates in Turkey have reached different findings. It is remarkable that it has been used KLSI as data collection tool in a great number of studies on the learning styles of prospective teachers in Turkey [24]. And nearly all of these studies have been reported that the accommodating is the least preferred learning style among the teacher candidates. Most of these studies are related to the learning styles of primary school teacher candidates [25-33]. On the other hand, there are less studies on the learning styles of prospective teachers studying in other teaching fields of education faculties in Turkey. For example, some of these studies are related to the learning styles of prospective geography [33], science [34-35], physics [36], biology [37], chemistry [38], mathematics [39-41], Turkish language education [42], music [43-44], computer and instructional technologies [45-46], physical education and sports [47] teachers. Besides this, in some of these studies it has been compared learning styles of teacher candidates studied in different departments of education faculties in Turkey [48-51]. When the literature on learning styles of teacher candidates in Turkey and may be in other countries is reviewed, it is seen that only study which is all of study sample is composed of social studies teacher candidates have been conducted by Özdemir and Kesten [52].

There are two main reasons why the sample of current work consists of social science teacher candidates:

Firstly, when the literature on learning styles is reviewed, it is noteworthy that there is lack of information related to the learning styles of teachers or teacher candidates of social studies courses. The social studies is a multidisciplinary course taught in $4^{\text {th }}-7^{\text {th }}$ grades in Turkish education system and which includes seven major social sciences (history, geography, anthropology, sociology, psychology, politics and economy). National Council for the Social Studies (NCSS) in USA defines social studies as "the integrated study of the social sciences and humanities to promote civic competence [53]." In this respect, teachers of this multidisciplinary course are expected to have different learning styles.

The other reason is to lead the next longitudinal work about the effectiveness of the curriculum in teacher education programs in Turkey on the learning styles of teacher candidates, in the case of social science teacher candidates.

The sub-problems of the current work within these general 
objectives are as follows:

1. What are the dominant learning styles of prospective teachers of social studies?

According to the data obtained based on Kolb's learning styles inventory,

2. Is there a significant difference between the learning styles in their first and last study years of prospective teachers of social studies?

3. Is there a significant difference between the learning styles in their first and last study years of prospective teachers of social studies in terms of gender variable?

\section{Materials and Methods}

This study was conducted according to a longitudinal methodology, which is one of the research designs used in developmental psychology research. These kinds of developmental researches are conducted to analyze the changes in specific behaviors of the same individuals within different time frames [54]. Such longitudinal studies have been conducted concerning the learning styles of Kolb, and it is reported in these studies that shows increasing movement in learning style from a reflective to an active orientation through the college years $(5,55-56)$. It should be noted, however, that the present study is not an experimental study in which any particular teaching method or technique is practiced. This is a descriptive study that the four-year undergraduate program of prospective teacher candidates participating in the study tested whether they had any effect on their learning styles.

The sample of the study consisted of prospective teachers studying in the Department of Social Studies Teaching of Faculty of Education of Ondokuz Mayis University in Turkey between the years 2009-2013. Kolb's learning style inventory version 3 (KLSI 3 ) was used as data collection tool in the study. The prospective teachers who participated in the study responded to KLSI 3 two times within first and last years of their undergraduate education. It should be noted that this sample is teacher candidates at the first grade level in Özdemir and Kesten's study. However, while there were 92 prospective teachers participated to study in the first year (in fall semester of 2009-2010 academic year) [52], 70 of these prospective teachers volunteered to participate to study in the last year (in spring semester of 2013-2014 academic year). Thus, the sample of the current study consists of 70 prospective teachers of social studies who participated in both data collections, and $39(56 \%)$ of whom were male and $31(44 \%)$ of whom were female.

In its current form, the LSI-3 (56Kolb, 1999) consists of 12 sentence stems followed by four possible sentence endings. The subject ranks each of the four sentence endings based on his or her preference for using the four modes. For example, a person would rank his or her greatest preference for learning as 4, second greatest preference as 3, then 2 and his or her least preference method as 1 . This ranking process would occur 12 times. The result is a 48 item survey. A total scale score is tabulated for each of the four modes. Finally, a combined score for each of the two bi-polar dimensions is computed, resulting in two dimensional scores that measure relative preference for the concrete experience (CE)abstract conceptualization (AC) mode and the active experimentation (AE)-reflective observation (RO) dimensions (57Kayes, D. C. (2005). The scores taken at the end of this process vary between -36 and +36 . The positive score taken from AC-CE dimensions shows that learning is abstract, while the negative score shows that learning is concrete. Similarly, the positive score taken from AE-RO dimensions show that learning is active and the negative score shows that learning reflective. These modes can be depicted along two continuums or dimensions - perceiving, the extent to which an individual emphasizes abstractness over concreteness ( $\mathrm{AC}-\mathrm{CE}$ continuum), and processing, the extent to which an individual emphasizes action over reflection (AE-RO continuum). An individual's learning style represents a combination of the two independent dimensions [58]. The four resulting learning styles are diverging $(\mathrm{CE} / \mathrm{RO})$, assimilating $(\mathrm{AC} / \mathrm{RO})$, converging (AC/AE), and accommodating (CE/AE) (see Fig. 1). At the last stage, it is determined as to where each learning style intersection area

The intersection point of these two combination scores on the learning style type grid was determined. The AE-RO point is on the $\mathrm{x}$-axis, while the AE-RO point is on the y-axis. The four types of learning styles of accommodating, diverging, assimilating, and converging represent each field on the coordinates. At the last stage, it is determined as to where each learning style intersection area is located and the learning style of the participant is determined. Because of learning styles are nominal values non-parametric tests were used in the analysis of the data. For this, the chi-square $\left(\chi^{2}\right)$ was used to analysis the relationship between genders and learning styles, while the wilcoxon signs test was used to analyze the difference between learning styles of the prospective teachers participated to study in the first and the last year of studies of their undergraduate education.

In contrast, learning modes (CE; AC, $\mathrm{AC}$ and $\mathrm{RO}$ ) are not nominal values. Firstly, the values related to inventory are converted to $\mathrm{Z}$ scores. In order to determine the normal distribution status of these scores, the histograms, distribution curves, skewness-kurtosis, and Kolmogorow Smirnow (K-S) normality test values were examined. When we see the K-S test results in Table 1, there is a significant deviation from normality at the scores of RO-1, AE-1 and AE-4 ( $p<0.05)$, whereas this results for CE-1, AC-1, CE-4, RO-4, AC-4 scores are normal distribution. Thus, the $t$ test was used to compare CE-1, AC-1, CE-4, RO-4, AC-4 scores for independent values, while paired samples t-test was used to find out whether there was significant difference between pre-test and post-test scores of these learning modes. Whereas in the analysis of scores which were not normally distributed, non-parametric equivalents of these tests were. 
Table 1. Kolmogorov-Smirnov test results conducted to examine the normality of the distribution of pre-test and post-test integrated skills

\begin{tabular}{|c|c|c|c|c|c|}
\hline & & \multicolumn{4}{|c|}{ Pretest (study year 1) } \\
\hline & & CE-1 & $\mathrm{RO}-1$ & $\mathrm{AC}-1$ & AE-1 \\
\hline & $\mathrm{N}$ & 70 & 70 & 70 & 70 \\
\hline \multirow{2}{*}{ Parameters } & $\chi$ & 25,3 & 29,5 & 33,2 & 32 \\
\hline & ss & 5,04 & 5,47 & 4,15 & 5,10 \\
\hline \multicolumn{2}{|c|}{ K-Smirnov Z } &, 86 &, 93 &, 74 & 1,03 \\
\hline & $\mathrm{p}$ &, 06 &, $03 *$ & ,20 &, $01 *$ \\
\hline & & \multicolumn{4}{|c|}{ Posttest (study year 4) } \\
\hline & & CE-1 & RO-1 & AC-1 & $\mathrm{AE}-1$ \\
\hline & $\mathrm{N}$ & 70 & 70 & 70 & 70 \\
\hline \multirow{2}{*}{ Parameters } & $\chi$ & 26,91 & 27,75 & 32,58 & 32,73 \\
\hline & ss & 4,96 & 5,11 & 5,07 & 5,07 \\
\hline \multicolumn{2}{|c|}{ K-Smirnov Z } &, 83 &, 76 &, 87 & 1,18 \\
\hline & $\mathrm{p}$ &, 09 & ,20 &, 06 &, $00 *$ \\
\hline
\end{tabular}

\section{Findings}

According to data obtained from KLSI-3, the pretest- posttest dominant learning styles of prospective teachers participated in the study can be seen in Table 2. Accordingly, the dominant learning style of almost half of the prospective teachers who participated in the study (n: $32,46 \%$ ) in the first year of their undergraduate education is assimilating. The number of number of prospective teachers who have this learning style decreases in the last year of their undergraduate education (n: 17, 24\%). On the other hand, while the total number of prospective teachers who had converging learning style remained the same (n: $23, \% 33)$, the number of prospective teachers who had accommodating learning style was only $2(6 \%)$ in their first year of study while it was increased to $11(16 \%)$ in their last year of study. And the number of prospective teachers who had diverging learning style was $11(16 \%)$ in their first year of study and $19(27 \%)$ in their last year of study. In addition, the Chi-square analysis results related to the gender in the learning mode scores indicate that there is no significant difference in the learning mode scores both in the first year of study and in the fourth year of study $\left(\chi^{2}(1)=0,339, p=0,93 ; \chi^{2}(4)=1,339\right.$, $\mathrm{p}=0,72)$.

Table 2. Chi-square $\left(\chi^{2}\right)$ Analysis results showing the association between learning styles and gender

\begin{tabular}{|c|c|c|c|c|c|c|c|c|c|c|}
\hline \multirow{3}{*}{ Groups } & \multicolumn{8}{|c|}{ Learning styles (study year 1) } & \multirow{2}{*}{\multicolumn{2}{|c|}{ Total }} \\
\hline & \multicolumn{2}{|c|}{ Diverging } & \multicolumn{2}{|c|}{ Assimilating } & \multicolumn{2}{|c|}{ Converging } & \multicolumn{2}{|c|}{ Accommodating } & & \\
\hline & $\mathrm{N}$ & $\%$ & $\mathrm{~N}$ & $\%$ & $\mathrm{~N}$ & $\%$ & $\mathrm{~N}$ & $\%$ & $\mathrm{~N}$ & $\%$ \\
\hline $\mathrm{M}$ & 7 & 18 & 18 & 46 & 12 & 31 & 2 & 5 & 39 & 56 \\
\hline $\mathrm{F}$ & 4 & 13 & 14 & 45 & 11 & 36 & 2 & 7 & 31 & 44 \\
\hline \multirow[t]{2}{*}{$\mathrm{T}$} & 11 & 16 & 32 & 46 & 23 & 33 & 4 & 6 & 70 & \\
\hline & \multicolumn{8}{|c|}{ Learning styles (study year 4 ) } & & \\
\hline $\mathrm{M}$ & 12 & 31 & 9 & 23 & 11 & 28 & 7 & 18 & 39 & 56 \\
\hline $\mathrm{F}$ & 7 & 23 & 8 & 26 & 12 & 39 & 4 & 13 & 31 & 44 \\
\hline $\mathrm{T}$ & 19 & 27 & 17 & 24 & 23 & 33 & 11 & 16 & 70 & \\
\hline
\end{tabular}

$\left(\chi^{2}(1)=0,339, p=0,93 ; \chi^{2}(4)=1,339, p=0,72\right)$

The Wilcoxon analysis results on the difference in prospective teachers' learning styles between their first and fourth year of study (Table 3 ) show that undergraduate education does not cause significant differences in learning styles of social studies teacher candidates $(T=596, p=0,68 ; z=-0,424)$. Similarly, analysis results show that undergraduate education of prospective teachers does not cause significant differences in learning styles in terms of gender $(T($ male $)=173, p=0,69$; $\mathrm{z}=-0,396 ; \mathrm{T}($ female $)=132, \mathrm{p}=0,85 ; \mathrm{z}=-0,189)$.

Table 3. The Wilcoxon analysis results on the difference in the learning styles of prospective teachers between their first and fourth year of study.

\begin{tabular}{|c|c|c|c|c|c|c|}
\hline G & Pre-post test & $\mathrm{N}$ & Mean Rank & Sum of Rank & $\mathrm{Z}$ & $\mathrm{p}$ \\
\hline \multirow{3}{*}{$\mathrm{T}$} & Negative Ranks & 24 & 24,83 & 596 & \multirow{3}{*}{$-0,424$} & \multirow{3}{*}{,68 } \\
\hline & Positive Ranks & 26 & \multirow{2}{*}{26,12} & \multirow{2}{*}{679} & & \\
\hline & Ties & 20 & & & & \\
\hline \multirow{3}{*}{ M } & Negative Ranks & 13 & 13,31 & 173 & \multirow{3}{*}{,- 396} & \multirow{3}{*}{,69 } \\
\hline & Positive Ranks & 14 & \multirow{2}{*}{14,64} & \multirow{2}{*}{205} & & \\
\hline & Ties & 12 & & & & \\
\hline \multirow{3}{*}{$\mathrm{F}$} & Negative Ranks & 11 & 12,00 & 132 & \multirow{3}{*}{,- 189} & \multirow{3}{*}{, 85} \\
\hline & Positive Ranks & 12 & \multirow{2}{*}{12,00} & \multirow{2}{*}{144} & & \\
\hline & Ties & 8 & & & & \\
\hline
\end{tabular}


According to Kolb's Experiential Learning Theory (ELT) briefly mentioned in the introduction, when individuals have to learn a new knowledge, they perceive this new knowledge through either concrete experience (CE) or abstract conceptualization (AC). Further on, they process to this perceived knowledge through either reflective observation (RO) or active experience (AE) [1-4]. For example, an individual with assimilating learning style perceive knowledge through abstract conceptualization and they process this perceived knowledge through reflective observation. In order to answer to the question of whether the undergraduate education of prospective teachers cause a significant change in their information perception continuum and information processing continuum, prospective teachers' concrete experience, reflective observation, abstract conceptualization and active experience scores in their first and last year of study were calculated, and subsequently the four basic learning style types-Accommodating, Diverging, Assimilating, and Converging-are created by dividing the AC-CE and AE-RO scores at the fiftieth percentile of the total norm group and plotting them on the Learning Style Type Grid (Figure 2). The cut point for the AC-CE scale is +7 , and the cut point for the AE-RO scale is +6 . The Accommodating type would be defined by an AC-CE raw score $<=7$ and an AE-RO score $>=7$, the Diverging type by AC-CE $<=7$ and $\mathrm{AE}-\mathrm{RO}<=6$, the Converging type by AC-CE $>=8$ and $\mathrm{AE}-\mathrm{RO}>=7$, and the Assimilating type by AC-CE $>=8$ and $\mathrm{AE}-\mathrm{RO}<=6$ [3]. As Figure 2 shows, in both the first and last years of undergraduates' education, the dominant learning style of total sample, male and female samples is the assimilating. However, it is observed that the male teacher candidates are slightly changed to active experimentation from reflective observation in the process of information processing.

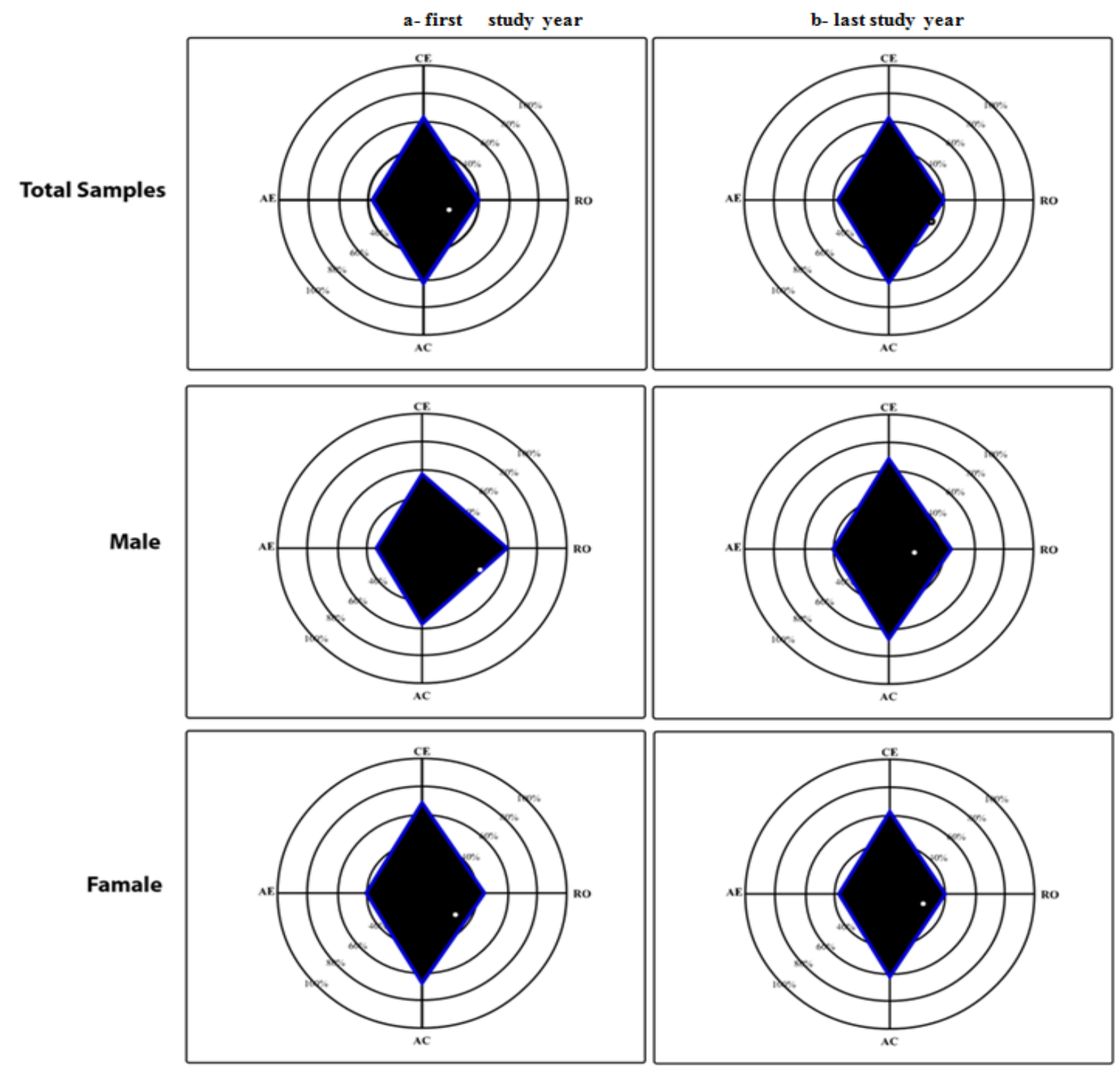

Figure 2. The dominant learning styles and concrete experience, reflective observation, abstract conceptualization and active experience scores of the study sample in their first and last years of study according to all samples and gender 
As can be seen from the related tables (Tables $4 \mathrm{a}, \mathrm{b}, \mathrm{c}$ ) which show the results of this analysis conducted, the difference between prospective teachers' perception continuum (concrete experience and abstract conceptualization) scores in their first year of study and fourth year of study was not found to be statistically significant.

In other words, undergraduate education of prospective teachers did not cause a significant difference in their ways of perceiving knowledge. However, the posttest concrete experience average scores were found to be even a little higher than pretest average scores, while posttest abstract conceptualization average scores were found to be lower than pretest average scores. Therefore, this results can bring to mind that four-year undergraduate education of social science teacher candidates may have led to a slight change to concrete from abstract on their information perception continuum; but this change is not significant statistically.

Table 4-a. Paired Samples t Test results of the difference between pre-test and post-test integrated scores

\begin{tabular}{|c|c|c|c|c|c|c|c|}
\hline & Assessment & $\mathrm{N}$ & Mean & $\mathrm{S}$ & sd & $\mathrm{t}$ & $\mathrm{p}$ \\
\hline \multirow{4}{*}{$\mathrm{T}$} & CE-1 & 70 & 25,31 & 5,04 & \multirow{4}{*}{69} & \multirow{2}{*}{1,94} & \multirow{2}{*}{0,56} \\
\hline & CE-4 & 70 & 27,00 & 5,96 & & & \\
\hline & $\mathrm{AC}-1$ & 70 & 33,23 & 4,15 & & \multirow{2}{*}{0,83} & \multirow{2}{*}{0,41} \\
\hline & $\mathrm{AC}-4$ & 70 & 32,60 & 5,07 & & & \\
\hline \multirow{4}{*}{ M } & CE-1 & 39 & 25,36 & 5,35 & \multirow{4}{*}{38} & \multirow{2}{*}{1,38} & \multirow{2}{*}{0,18} \\
\hline & CE-4 & 39 & 26,85 & 4,44 & & & \\
\hline & $\mathrm{AC}-1$ & 39 & 33,08 & 4,25 & & \multirow{2}{*}{0,99} & \multirow{2}{*}{0,33} \\
\hline & AC-4 & 39 & 32,03 & 5,52 & & & \\
\hline \multirow{4}{*}{$\mathrm{F}$} & CE-1 & 31 & 25,26 & 4,70 & \multirow{4}{*}{30} & \multirow{2}{*}{1,35} & \multirow{2}{*}{0,18} \\
\hline & CE-4 & 31 & 27,00 & 5,63 & & & \\
\hline & $\mathrm{AC}-1$ & 31 & 33,42 & 4,09 & & \multirow{2}{*}{0,11} & \multirow{2}{*}{0,91} \\
\hline & AC-4 & 31 & 33,29 & 4,44 & & & \\
\hline
\end{tabular}

According to Kolb's Experiential Learning Theory, in terms of the scores of reflective observation and active experimentation, which are the ways to process perceived information, the difference between the first and last year scores of prospective teachers was not found to be statistically significant ( Table 4 b, c).

Table 4-b. Wilcoxon Signed Ranks Test results of the difference between KLSI-3 pre-test and post-test Reflective Observation (RO) integrated scores

\begin{tabular}{|c|c|c|c|c|c|c|}
\hline Groups & Pre-post test & $\mathrm{N}$ & Mean Rank & Sum of Rank & Z & $\mathrm{p}$ \\
\hline \multirow{3}{*}{$\mathrm{T}$} & Negative Ranks & 43 & 33,74 & 1451 & \multirow{3}{*}{1,70} & \multirow{3}{*}{0,09} \\
\hline & Positive Ranks & 25 & \multirow{2}{*}{35,80} & \multirow{2}{*}{895} & & \\
\hline & Ties & 2 & & & & \\
\hline \multirow[b]{2}{*}{ M } & Negative Ranks & 25 & 19,12 & 478 & \multirow[b]{2}{*}{1,91} & \multirow[b]{2}{*}{0,06} \\
\hline & Positive Ranks & 12 & 18,75 & 225 & & \\
\hline \multirow{5}{*}{$\mathrm{F}$} & Negative Ranks & 18 & 15,28 & 275 & \multirow{5}{*}{0,53} & \multirow{5}{*}{0,60} \\
\hline & Positive Ranks & 13 & \multirow{2}{*}{17,00} & \multirow{2}{*}{221} & & \\
\hline & Ties & 0 & & & & \\
\hline & Positive Ranks & 13 & \multirow{2}{*}{16,38} & \multirow{2}{*}{213} & & \\
\hline & Ties & 1 & & & & \\
\hline
\end{tabular}

Table 4-c. The Wilcoxon Signed Ranks Test results of the difference between pre-test and post-test Active experience (AE) integrated scores

\begin{tabular}{|c|c|c|c|c|c|c|}
\hline Groups & Pre-post test & $\mathrm{N}$ & Mean Rank & Sum of Rank & $\mathrm{Z}$ & $\mathrm{p}$ \\
\hline \multirow{3}{*}{$\mathrm{T}$} & Negative Ranks & 31 & 33,76 & 1047 & \multirow{3}{*}{0,77} & \multirow{3}{*}{0,44} \\
\hline & Positive Ranks & 37 & \multirow{2}{*}{35,12} & \multirow{2}{*}{1300} & & \\
\hline & Ties & 2 & & & & \\
\hline \multirow[b]{2}{*}{ M } & Negative Ranks & 14 & 19,46 & 273 & \multirow[b]{2}{*}{1,42} & \multirow[b]{2}{*}{0,16} \\
\hline & Positive Ranks & 24 & 19,52 & 469 & & \\
\hline \multirow{3}{*}{$\mathrm{F}$} & Negative Ranks & 17 & 14,82 & 252 & \multirow{3}{*}{0,40} & \multirow{3}{*}{0,69} \\
\hline & Positive Ranks & 13 & \multirow{2}{*}{16,38} & \multirow{2}{*}{213} & & \\
\hline & Ties & 1 & & & & \\
\hline
\end{tabular}


As can be seen in the related table (Table $4 \mathrm{a}, \mathrm{b}, \mathrm{c}$ ), similar results were found when these analyses were conducted based on the variable of gender. Four-year-long undergraduate education was not found to create a significant change in perception continuum and processing continuum of both male and female prospective teachers.

\section{Discussion}

The results of this study conducted according to a longitudinal methodology and examined the effect of four-year-long field education on the learning styles of prospective teachers of social studies can be summarized as follows:

a- It is determined also Kolb's four learning styles among the dominant learning styles in both first and last study years of prospective teachers of social studies who answered KLSI twice. However, it is remarkable that the dominant learning style of almost two thirds of prospective teachers in their first year of study and almost half of prospective teachers in their fourth year of study was either assimilating or converging. Özdemir and Kesten's [52] study conducted with 380 prospective teachers of social studies in different years of study are similar to those of the present study. The researchers reported that the dominant learning style of $38,4 \%$ of the sample was assimilating, while the dominant learning styles of $37,9 \%$ was converging, $13,7 \%$ was diverging and $10 \%$ was accommodating.

It is noteworthy that similar results have been found in previous studies conducted on Kolb learning styles of prospective teachers and studying in different departments of education faculties in Turkey. In some of these studies, it was found that the dominant learning style of prospective teachers was assimilating or converging [23-33, 56]. For example, in a study of Özdemir [33] which compared the learning styles of geography and geography teaching undergraduates studied in different universities of Turkey, it was reported that a great majority of prospective teachers of geography had converging and assimilating learning styles. However, it was found that the dominant learning styles of prospective teachers studying in departments related with physical sciences such as science [34-35], physics [36], biology [37] and chemistry [38] was diverging; while the dominant learning styles of prospective teachers of mathematics was converging [39-41] and the dominant learning styles of prospective teachers of Turkish language were either converging $[42,59]$ or assimilating [48]. In one of the two studies which were about the learning styles of prospective teachers studying in fields that required special skills such as music, the dominant learning style of a great majority of prospective teachers of music was reported to be diverging or accommodating [43], while in the other one [44] the dominant learning styles of prospective teachers were reported to be assimilating and diverging. In other study, it was found that the dominant learning styles of a great majority of prospective teachers of physical education and sport was either diverging or assimilating [47]. The dominant learning styles of prospective teachers of computer and instructional technologies teaching (CITT) which requires information and skills about information technology were reported to be converging [45-46]. In a study which included prospective teachers of primary school education, CITT, science education, art education, social studies and Turkish language teaching in different years of study, Kazu [61] reported that the two dominant learning styles were assimilating and converging, and there were no significant differences in the learning styles of prospective teachers in terms of the field of education.

b- It was found that the number of assimilating learning styles decreased in favor of the accommodating learning style among the social science teachers participating in the survey in the last grade. However, there was no statistically significant difference between the pre-posttests. Furhermore, in the context of experiential learning theory, prospective teachers' undergraduate education did not cause a significant difference in their perception continuum (CE-AC) and processing continuum (RO-AE) dimensions.

However, in their previous study, Özdemir and Kesten [52] have reported that there are four learning styles at each grade level from first year to fourth year, but almost half of the pre-service teachers in the first grade had assimilation (52\%), while the proportion of this style decreased as the class level increased. They found that nearly half (43\%) of the teacher candidates in the final grade had converging learning style. Another remarkable result of this study was the decrease in assimilating learning style (19\%) in fourth year of study, while the least observed learning style of prospective teachers of social studies was accommodating learning style, the frequency of this learning style was two times more in prospective teachers in their fourth year of study when compared with other years of study.

Most of the studies which have examined whether there is difference between the learning styles of prospective teachers in terms of the variable of year of study have concluded that there are differences in the learning styles of prospective teachers especially in their first and fourth years of study [28-323, 36, 39, 48-50, 59-61].

Another study which assessed the learning styles of the same sample group in different stages of their education is Tsang's study [62]. In this study, the researcher applied Kolb learning styles inventory to studies studying in a social work programme of a university in Hong Kong at four different points of their education. The researcher found that students who started out as accommodators at the beginning of the course and were exposed to classroom learning of academic and practice-oriented subjects became assimilators at the end of their first year. The learning mode switched again to converger at the end of the second year, during which students combined academic study with fieldwork placements. 
a. Based on the variable of gender, no statistically significant difference was found between the learning styles of male and female prospective teachers in both assessments. In addition, it was found that the undergraduate education of prospective teachers was not effective in causing a significant difference in the learning styles, perception continuum and processing continuum in terms of gender.

In most of the studies conducted with Turkish prospective teachers on the subject $[30,32-37,42,46,48]$, it was found that gender did not cause a significant difference on learning styles. However, in some of these studies, it can be seen that gender is effective on learning styles [27, 29, 31, 59].

First studies conducted with Kolb's learning styles inventory show that men were found to be more abstract than women in AC-CE scales and there were no significant gender differences in AE-RO dimension [3, 63-64]. The results of the present study which used KLSI 3.1 normative sample as data collection tool show similar significant gender differences on AC-CE and smaller but significant differences on AE-RO [3]. These results need to be interpreted carefully, since educational specialization and career choices often interact with gender differences [65].

\section{Conclusions}

As a conclusion, four-year-long undergraduate education was not effective in causing a significant difference in the learning styles and learning ways of prospective teachers of social studies. However, since the sample of the present study is small, and there are no such longitudinal studies already on learning styles of teacher candidates in Turkey, it would not be correct to make a generalization based on the findings of this research. Contrary to all earlier studies on prospective teachers' learning styles in Turkey, the reason why the findings of the present longitudinal study are not meaningful may be related to the personality traits of the sample or the teaching process. For this reason the findings of the study need to be supported by similar longitudinal studies.

Nevertheless, the previous studies conducted on the prospective teachers' the learning styles show that the dominant learning style of most of the prospective teachers in Turkey is assimilating. As stated by Kolb, workers in the field of education are expected to have accommodating learning style, which is a combination of concrete experience and active experimentation because the profession of teaching is not just about transferring what one knows. Smilarly, Nulty and Barrett [66] and Kruzich et al. [67] concluded that field of education were predominantly accommodating.

However, in all of the studies concerned with Kolb' learning styles of prospective teachers in Turkey given some examples above, it has been reported that this learning style is the least preferred learning style among the teacher candidates. This result may be related to teaching methods and the curricula of education faculties in Turkey [68-69], because most of the lessons in curriculum of the education faculties in Turkey are field courses such as history, geography and biology. For example, in the social studies teacher curriculum studied by the study sample, there are a total of 136 hours of compulsory theoretical lectures per week spread into 8 semesters. None of the courses in the first four semesters of this program are practical courses in which students are active in classes. The social studies teacher candidates are faced with this kind of course in the last four semesters of undergraduate education. However, all these practical courses (teaching technique and material design, collective service practices, special teaching methods, drama, social project development and teaching experience in public schools), are 26 hours per week spread over four semesters (4 hours a week in the 5th semester, 6 hours a week in the 6 th semester, 8 hours a week in the 7 th semester, 10 hours a week in the 8 th semester or last semester). And also, this field courses in curriculum are usually carried out with teacher-centered teaching methods, which are favored by individuals with assimilating learning style has AC and RO as dominant learning abilities. In formal learning situations, people with assimilating learning style prefer readings, lectures, exploring analytical models, and having time to think things through. Whereas an individual with an accommodating style has $\mathrm{CE}$ and $\mathrm{AE}$ as dominant learning abilities. People with this learning style have the ability to learn from primarily "hands-on" experience. In formal learning situations, people with the accommodating learning style prefer to work with others to get assignments done, to set goals, to do field work, and to test out different approaches to completing a project [1-4]. However, in the curriculum of education faculties in Turkey, the number or hours of lessons that allow such experiences are considerably less than in other field courses that students are passive listeners during class hours.

As can be understood from studies conducted on proficiencies of teachers in Turkey, teachers should have general proficiencies such as planning and organizing the process of teaching, the process of learning-teaching, following and assessing, cooperating with school-family and the society and occupational development. Within the framework of these five general teaching proficiencies, proficiencies of each teaching field have been determined [70]. For example, it have been examined a total of 20 proficiencies specific for social studies teaching. In order to acquire skills related to these qualifications, it should be a suitable way of learning for prospective teachers to perceive knowledge through concrete experiences and to process knowledge through active learning. In order to gain such skills necessary for the teaching profession, the training process of education faculties should contribute to development of skills suitable to the necessities of teaching 
profession. Therefore, teaching strategies used by instructors in university education systems need to be changed and improved with more student-centred ones. Starting from first year in the university programs, problem-solving and collaborative learning strategies should be implied in the universities, and after that, follow up studies should be conducted to see whether these strategies make any differences on prospective teachers' learning styles or not.

\section{Acknowledgements}

We are very grateful to graphic design expert Figen Sarışan designed the figures on this article for her contributions.

\section{REFERENCES}

[1] A. Kolb, D. A. Kolb. Experiential Learning Theory Bibliography, Online available fromhttp://learningfromexper ience.com/lfe_research_lib_doc_type/bibliography/

[2] A. Y. Kolb, D. A. Kolb. The Kolb Learning Style Inventory-Version 3.1 2005 Technical Specifications, MA: Hay Resource Direct, Boston, 2005.

[3] D. A. Kolb. Learning styles and disciplinary differences, The Modern American College, San Francisco, 1981

[4] A. Y. Kolb, D. A. Kolb. Learning styles and learning spaces: Enhancing experiential learning in higher education, Academy of Management Learning \& Education, Vol. 4, No: 2, 193-212, 2005

[5] M. Healey, P. Kneale, J. Bradbeer. Learning styles among geography undergraduates: an international comparison, Area, Vol. 37, No. 1, 30-42, 2005.

[6] D. A. Kolb, R. E. Boyatzis, C. Mainemelis. Experiential Learning Theory: Previous Research and New Directions, Online available from http://www.d.umn.edu/ kgilbert/educ5165731/Readings/exp erientiallearning-theory.pdf

[7] C. Mainemelis, R.E. Boyatzis, D.A. Kolb. Learning styles and adaptive flexibility: testing experiential learning theory, Management Learning, Vol. 33, No.1, 5-33, 2002.

[8] B. Bradbeer. Barriers to Interdisciplinary: Disciplinary discourses and student learning, Journal of Geography in Higher Education, Vol. 23, No.3, 381-396, 1999.

[9] C. Jones, C. Reichard, K. Mokhtari. Are students' learning styles discipline specific?, Community College Journal of Research \&Practice, Vol. 27, No. 5, 363-375. 2003.

[10] A. D'Amore, S. James, E. K. Mitchell. Learning styles of first-year undergraduate nursing and midwifery students: A cross-sectional survey utilising the Kolb Learning Style Inventory, Nurse Education Today, Vol. 32, No. 5, 506-515, 2012.
[11] C.M. Baker, D.J. Pesut, A.M.. McDaniel, M.L. Fisher. Evaluating the impact of problem-based learning on learning styles of master's students in nursing administration, Journal of Professional Nursing, Vol. 23, No. 4, 214-219, 2007.

[12] J. A. Gyeong, S. Y. Myung. Critical thinking and learning styles of nursing students at the baccalaureate nursing program in Korea, Contemporary Nurse, Vol. 29, No. 1, 100109, 2008.

[13] W. A. Suliman. The relationship between learning styles, emotional social intelligence, and academic success of undergraduate nursing students, Journal of Nursing Research, Vol. 18, No. 2, 136-143, 2010.

[14] P. Hauer, C. Straub, S. Wolf. Learning styles of allied health students using Kolb's LSI-II a, Journal of Allied Health, Vol. 34, No. 3, 177-182, 2005.

[15] A. Smith. Learning styles of registered nurses enrolled in an online nursing program, Journal of Professional Nursing, Vol. 26, No. 1, 49-53, 2010.

[16] D. A. ALQahtani, S. M. Al-Gahtani. Assessing learning styles of Saudi dental students using Kolb's Learning Style Inventory, Journal of Dental Education, Vol. 78, No. 6, 927-933. 2014.

[17] E. Gürpınar, M. K. Alimoğlu, S. Mamaklı, M. Aktekin. Can learning style predict student satisfaction with different instruction methods and academic achievement in medical education?, Advances in Physiology Education, Vol. 34, No. 4, 192-196, 2010.

[18] B. A. Adesunloye, O. Aladesanmi, F. M. Henriques, C. Ivonye. The preferred learning style among residents and faculty members of an internal medicine residency program, Journal of the National Medical Association, Vol. 100, No. 2, 172$175,2008$.

[19] A. Koşan, M. Demirören, S. Kemahlı, Ö. Palaoğlu, İ. Ayhan. Ankara Üniversitesi Tıp Fakültesinde tıp eğitimine başlayan öğrencilerin öğrenme stilleri, Tıp Eğitimi Dünyası, Vol. 8, No. $25,1-9,2007$.

[20] P.B. Smits, J.H. Verbeek, M.C. Nauta, J.Y. Cate, C.M. Metz, F.C. Dijk. Factors predictive of successful learning in postgraduate, Medical Education, Vol. 38, No. 7, 758-766, 2004.

[21] P. T. Engels, C. de Gara. Learning styles of medical students, general surgery residents, and general surgeons: implications for surgical education, BMC Medical Education, Vol. 10, No. $1,51-56,2010$

[22] O. Ö. Demirbaş, H. Demirkan. Focus on architectural design process through learning styles, Design Studies, Vol. 24, No. 5, 437-456, 2003.

[23] E. Yeşilyurt. Determination of teachers' learning styles and evaluation of the relationship among learning styles, Journal of Theory and Practice in Education, Vol. 10, No. 4, 999-1021, 2014.

[24] M. K. Demir. Sınıf öğretmeni adaylarının öğrenme stilleri ve sosyal bilgiler öğretimi, Eurasian Journal of Educational Research, Vol. 23, 28-37, 2006.

[25] Ö. Kaf Hasırcı. Sınıf öğretmenliği öğrencilerinin öğrenme stilleri: Çukurova Üniversitesi örneği, Journal of Theory and Practice in Education, Vol. 2, No. 1, 15-25, 2006. 
[26] B. Çaycı, E. Ünal. Sınıf öğretmeni adaylarının sahip oldukları öğrenme stillerinin çeşitli değişkenlere göre incelenmesi, Bilim, Eğitim ve Düşünce Dergisi, Vol. 7, No. 3, 1-16, 2007.

[27] M. Peker, Ş. Mirasyedioğlu. Pre-service elementary school teachers' learning styles and attitudes towards mathematics, Eurasia Journal of Mathematics, Science \& Technology Education, Vol. 4, No. 1, 21-26, 2008.

[28] E. Karademir, Ö. Tezel. Sınıf öğretmeni adaylarının öğrenme stillerinin demografik değişkenler açısından incelenmesi, Pamukkale Üniversitesi Eğitim Fakültesi Dergisi, Vol. 28, No. 2, 129-145, 2010.

[29] Ş. Can. Sınıf öğretmeni adaylarının öğrenme stilleri ile bazı değişkenler arasındaki ilişkinin araştırılması, Hacettepe Üniversitesi Eğitim Fakültesi Dergisi, No. 41, 70-82, 2011.

[30] G. Çiğdem, A. Memiş. Sınıf öğretmenliği adaylarının öğrenme stilleri ve öğretmenlik mesleğine yönelik tutumlarının çeşitli değişkenler açısından incelenmesi, Çukurova Üniversitesi Eğitim Fakültesi Dergisi, Vol. 40, No. 3, 57-77, 2011.

[31] İ. Turan. Sınıf öğretmen adaylarının öğrenme stillerinin coğrafya dersine yönelik tutumlarına ve akademik başarıları üzerine etkileri, Education Sciences, Vol. 9, No. 5, 1-16, 2015.

[32] S. Açışlı. Sınıf öğretmeni adaylarının öğrenme stilleri ile eleştirel düşünme eğilimlerinin incelenmesi, İlköğretim Online, Vol. 15, No. 1, 273-285, 2016.

[33] N. Özdemir. Türkiye'deki Üniversitelerin Coğrafya Bölümü Öğrencileri ile Coğrafya Öğretmenliği Bölümü Öğrencilerinin Öğrenme Stillerinin Karşılaştırılması, Coğrafyacılar Derneği Uluslararası Kongresi, Muğla Sitk Koçman Üniversitesi, 560-569, 2014.

[34] H. H. Bahar, A. Sülün. Fen bilgisi öğretmen adaylarının öğrenme stilleri, cinsiyet öğrenme stili ilişkisi ve öğrenme stiline göre akademik başarı, Kastamonu Eğitim Dergisi, Vol. 19, No. 2, 379-386, 2011.

[35] A. Köse. Fen bilgisi öğretmen adaylarının öğrenme stilleri, ders çalışma stratejileri ile fen bilgisi öğretimi öz yeterlik inançları arasındaki ilişki (ÇOMÜ örneği), (Yayınlanmamış Yüksek Lisans Tezi), Çanakkale Onsekiz Mart Üniversitesi, Sosyal Bilimler Enstitüsü, Çanakkale, 2010.

[36] Ş. Kandil İngeç. Turkish pre-service physics teachers' preferred learning styles, Educational Research and Reviews, Vol. 10, No. 4, 403-415, 2015.

[37] İ. Ü. Yapıcı, M. Hevedanlı. Biyoloji öğretmen adaylarının öğrenme stilleri ile biyoloji öğretimine yönelik öz-yeterlik inançları arasındaki ilişki, Electronic Journal of Education Sciences, Vol. 1, No: 1, 15-25, 2012.

[38] Ö. Özyalçın Oskay, E. Erdem, B. Akkoyunlu, A. Yılmaz. Prospective chemistry teachers' learning styles and learning preferences, Procedia-Social and Behavioral Sciences, Vol. 2, No: 2, 1362-1367, 2010.

[39] A. Tuna, A. Kaçar. The investigation of the learning styles of pre-service mathematics teachers by some variables, International Journal on New Trends in Education and Their Implication, Vol. 7, No. 2, 34-42, 2016.

[40] M. Peker. Pre-service teachers' teaching anxiety about mathematics and their learning styles, Eurasia Journal of
Mathematics, Science and Technology Education, Vol. 5, No. 4, 335-345, 2009.

[41] K. Özgen, B. Tataroglu, H. Alkan. An examination of multiple intelligence domains and learning styles of pre-service mathematics teachers: Their reflections on mathematics education, Educational Research and Reviews, Vol. 6, No. 2, 168-181, 2011

[42] T. Demir. Türkçe eğitimi bölümü öğrencilerinin öğrenme stilleri ve bunların çeşitli değişkenlerle ilişkisi (Gazi Üniversitesi örneği), Uluslararası Sosyal Araştırmalar Dergisi, Vol. 1, No. 4, 129-148, 2008.

[43] H. H. Okay. The relations between academic achievement in field lessons and learning styles of music teacher candidates, Procedia - Social and Behavioral Sciences, Vol. 51, 193-197, 2012.

[44] F. Altun, C. Yurga, O. Zahal, E. Gürpınar. Müzik öğretmeni adaylarının öğrenme stilleri ve alan dersleri başarıları arasındaki ilişkiler, e-International Journal of Educational Research, Vol. 6, No. 3, 46-70, 2015.

[45] A. Ateş, E. Altun. Bilgisayar ve öğretim teknolojileri eğitimi öğrencilerinin öğrenme biçemleri ve öğrenme tercihleri, Eurasian Journal of Educational Research, No. 30, 1- 16, 2008.

[46] H. Özgür. BÖTE bölümü öğretmen adaylarının öğrenme stillerinin çeşitli değişkenler açısından incelenmesi, Pamukkale Üniversitesi Eğitim Fakültesi Dergisi, No. 34, 103-118, 2013.

[47] C. Alemdağ, E. Öncü. Kolb öğrenme stili modeline göre beden eğitimi öğretmeni adayları, Alan Eğitimi Araştırmaları Dergisi, Vol. 1, No. 1, 1-12, 2015.

[48] K. Ünal, G. Dilbaz Alkan, F. B. Özdemir, Ö. Çakır. Eğitim fakültesi öğrencilerinin öğrenme stil ve stratejilerinin çeşitli değişkenler açısından incelenmesi (Mersin Üniversitesi Örneği), Mersin Üniversitesi Eğitim Fakültesi Dergisi, Vol. 9, No. 3, 56-76, 2013.

[49] K. Kırcaburun, Ş. Danişman. Examining the latitudinal variation of pre-service teachers' learning style profiles, EAJI (Asian Journal of Instruction), Vol. 4, No. 1, 45-58, 2016.

[50] M. Genç, M. Kocaarslan. Öğretmen adaylarının öğrenme stillerinin çeşitli değişkenler açısından incelenmesi: Bartın Üniversitesi örneği, Türkiye Sosyal Araştırmalar Dergisi, No. 172, 327-344, 2013.

[51] H. H. Bahar, R. Polat, M. Özbaş. Resim, müzik ve beden eğitimi öğretmen adaylarının öğrenme stilleri, Journal of Education Faculty, Vol. 18, No. 1, 409-424, 2016.

[52] N. Özdemir, A. Kesten. Sosyal bilgiler öğretmen adaylarının öğrenme stilleri ve bazı demografik değişkenlerle ilişkisi, Atatürk Üniversitesi Sosyal Bilimler Enstitüsü Dergisi, Vol. 16, No. 1, 361-377, 2012.

[53] NCSS. Curriculum standards for social studies: Expectations of excellence. Washington DC: National Council for the Social Studies, 1994.

[54] M. Bilgin, B.Yazgan İnanç, M. Kılıç Atıcı. Gelişim Psikolojisi, Çocuk ve Ergen Gelişimi, Pegem Akademi, Ankara, 2015. 
[55] M. Mentkowski, M. Strait. A longitudinal study of student change in cognitive development, learning styles, and generic abilities in an outcome-centered liberal arts curriculum. Final Report to the National Institutes of Education from Alverno College, 1983. Online from http://files.eric.ed.gov/fulltext/ED239562.pdf

[56] D. A. Kolb. Learning Style Inventory, version 3. Boston: The Hay Group, 1999.

[57] D.C. Kayes. Internal validity and reliability of Kolb's learning style inventory version 3 (1999). Journal of Business and Psychology, Vol. 20, No.2, 249-257, 2005.

[58] C. Manolis, D. J. Burns, R. Assudani, R. Chinta. Assessing experiential learning styles: A methodological reconstruction and validation of the Kolb Learning Style Inventory. Learning and individual differences, Vol. 23, 44-52, 2013.

[59] E. Kılıç, Ş. Karadeniz. Cinsiyet ve öğrenme stilinin gezinme stratejisi ve başarıya etkisi, Gazi Üniversitesi Gazi Eğitim Fakültesi Dergisi, Vol. 24, No. 3, 129-146, 2004.

[60] F. Kayan Fadlelmula. Pre-service Teachers' Learning Styles and Attitudes toward Teaching Profession, Turkish Journal of Teacher Education, Vol. 2, No. 4, No. 1, 55-63, 2015.

[61] İ. Y. Kazu. Learning styles of teacher candidates: A sample of Firat University, African Journal of Business Management, Vol. 4, No. 15, 3265-3276, 2010.

[62] N. M. Tsang. Shifts of students' learning styles on a social work course, Social Work Education, Vol. 12, No. 1, 62-76, 1993.
[63] D. A. Kolb. Learning Style Inventory: Technical Manual Boston, MA: Hay Group, Hay Resources Direct. 1976.

[64] D. A. Kolb. Learning Style Inventory: Technical Manual Boston, MA: Hay Group, Hay Resources Direct, 1985.

[65] L. Willcoxson, M. Prosser. Kolb's learning style inventory (1985): Review and further study of validity and reliability, The British Journal of Educational Psychology, Vol. 66, No. 2, 247-257, 1996.

[66] D. D. Nulty, M. A. Barrett. Transitions in students' learning styles, Studies in Higher Education, Vol. 21, No. 3, 333-345, 1996.

[67] J. M. Kruzich, J. F. Barbara, V. S. Dorothy. Assessment of student and faculty learning styles: Research and application, Journal of Social Work Education, Vol. 22. No. 3, 22-30, 1986.

[68] S. Demirezen. Sınıf Öğretmenlerinin Öğretim Stratejileri ile Öğretim Yöntem ve Tekniklerine İlişkin Görüşleri. Yayımlanmamış Yüksek Lisans Tezi, Hacettepe Üniversitesi Sosyal Bilimler Enstitüsü, Ankara, 2001.

[69] A. M.Taş. Sosyal bilgiler öğretmenliği eğitimi program standartlarının belirlenmesi. Ankara Üniversitesi Eğitim Bilimleri Fakültesi Dergisi, Vol. 37, No. 1, 28-54, 2004.

[70] Online available from; http://otmg.meb.gov.tr/belgeler/ogret men_yeterlikleri_kitabi/\%C3\%96\%C4\%9Fretmen_Yeterlikl eri $\overline{\mathrm{K} i t a b} \% \mathrm{C} 4 \% \overline{\mathrm{B}} 1$ sosyal bilgiler $\% \mathrm{C} 3 \% \mathrm{~B} 6 \% \mathrm{C} 4 \% 9$ Fretm eni_\%C3\%B6zel_alan_yeterlikleri_ilk\%C3\%B6\%C4\%9Fret im_par\%C3\%A7a_ 12.p. 